\title{
Patterns of cervical cancer mortality in young adult women in three countries of the European Union: Finland, Poland, and Latvia
}

\author{
Witold A. Zatoński1,2, Magdalena Pisarska-Krawczyk², Cezary Wojtyła³ ${ }^{3}$ Kinga Janik-Koncewicz ${ }^{1,4}$ \\ 'Health Promotion Foundation, Nadarzyn, Poland \\ ${ }^{2}$ Higher Vocational State School in Kalisz, Poland \\ ${ }^{3}$ Centre of Postgraduate Medical Education, I Department of Obstetrics and Gynaecology, Warsaw, Poland \\ ${ }^{4}$ Doctor of Philosophy (PhD) Candidate, University of Aberdeen, UK
}

\begin{abstract}
At the beginning of the $21^{\text {st }}$ century, our knowledge on the biology, etiology, diagnosis, prevention, and treatment of cervical cancer is close to complete. Essential tools for effective screening of cervical cancer already exist and are improving each year. Deaths from cervical cancer have become very rare in many parts of the world. Despite this, there are still countries, in which cervical cancer mortality levels have increased in the last decades. This is partly because the implementation of an effective cervical cancer programme is an extremely complex undertaking, from the organizational, medical, social, and economic points of view. Finland is one of the European countries, which have been able to develop some of the most optimal cervical cancer screening programmes. On the other hand, some countries of Central and Eastern European region have not been able to overcome the substantial challenges involved in building such a programme, and struggle with persistently high and often growing cervical cancer rates. In Poland, cervical cancer mortality rates have been declining since 1990s, but new challenges have emerged. Significant differences in mortality levels between social groups have arisen, as have the first symptoms of a lack of a sustainable population-based cervical cancer screening strategy in Poland.
\end{abstract}

KEY WORDS: cervical cancer, mortality rate, cancer prevention and control, European Union.

ADDRESS FOR CORRESPONDENCE: Witold A. Zatoński, Health Promotion Foundation, 51 Mszczonowska Street, 05-830 Nadarzyn, Poland, e-mail: wazatonski@promocjazdrowia.pl

\section{INTRODUCTION}

Presently, in the vast majority of developed countries, deaths from cervical cancer have become very rare. This is well illustrated by the changing trends in mortality from leading cancers in USA in the last hundred years (Fig. 1). However, in some countries, especially in Latin America and Asia, cervical cancer remains a leading cause of cancer mortality [1]. Epidemiological data also shows that while in most countries of Western Europe the problem of cervical cancer mortality has been tackled effectively in some Eastern European countries cervical cancer remains a major and often growing public health and social challenge [2-4].
Polish researchers played a significant role in building a scientific understanding of cervical cancer. The hypothesis about the viral causality of cervical cancer was developed by Professor Stefania Jabłońska and her team from Warsaw School of Medicine between the 1950s and 1970s [5-7]. Using Jabłońska's hypothesis, Professor Harald zur Hausen and his team in the German Cancer Research Center - Deutsches Krebsforschungszentrum (DKFZ) in Heidelberg characterised the human papillomavirus (HPV), and created HPV vaccination [8]. Numerous epidemiological studies indicated that almost all cervical cancers are connected to HPV. An international study by Bosch et al. [9] conducted in 22 countries, including 


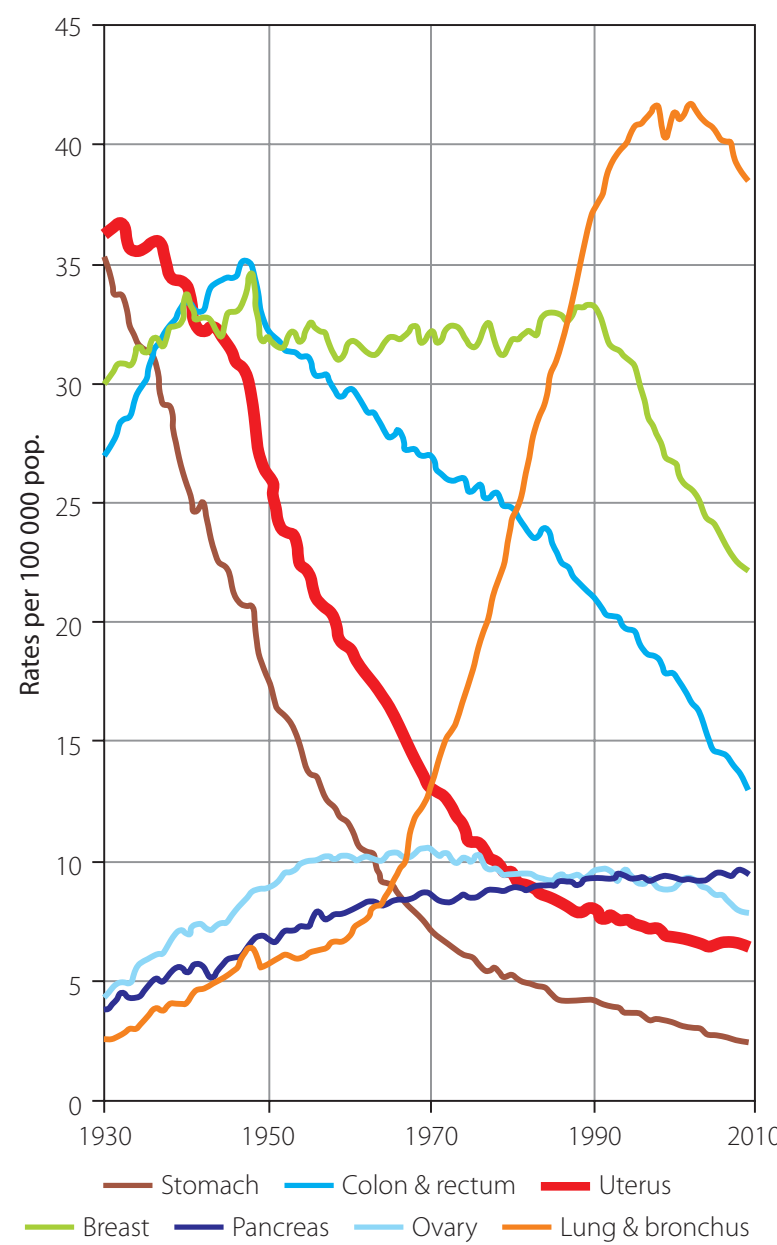

Source: Howlader N, Noone AM, Krapcho M, et al. (eds.). SEER Cancer Statistics Review, 1975-2009 (Vintage 2009 polulations), National Cancer Institute. Bethesda, USA. Available from: http://seer. cancer.gov/csr/1075_2009_pops09/ (based on November 2011 SEER data submission, posted to the SEER web site, April 2012).

FIG. 1. Cancer mortality among women in USA from 1930 to 2009

Poland, showed that $93 \%$ of cervical tumors were associated with HPV with no significant variation between countries. In the Polish sample, HPV 16 was detected in $80 \%$ of cases. A study conducted several years later by the Department of Epidemiology, Cancer Center in Warsaw, together with Sylvia Franceschi and her team from the International Agency for Research on Cancer (IARC) in Lyon, France [10], demonstrated the high burden (79\%) of HPV infection in Warsaw in women aged 18-59 years.

The Pap test, introduced to general clinical practice, in the first half of the $20^{\text {th }}$ century and modified through subsequent years, eventually became a tool for solid and simple early diagnosis of cervical cancer as well as the basis for effective secondary prevention programmes [2]. At the beginning of the 1960s, many Western European countries introduced population-based organised cervical cancer screenings for women. At the same time, countries of the communist Eastern Bloc attempted to solve the problem of cervical cancer with methods based on the clinically-focused Semashko model, with deep medicalisation and an assumption that every citizen should have access to free medical care [11]. Cervical cancer control through early diagnosis (Pap test) and treatment became part of the gynaecological routine, becoming the domain of highly specialised gynaecologists. In some Soviet Republics, such as Latvia or Russia, cytological smears became part of the compulsory preventive gynaecological examination from 1960. This practice correlates with the subsequent decline of cervical cancer incidence and mortality in these Soviet Union Republics [12, 13]. However, at the end of the 1980s, the system of gynaecological care in the Eastern Bloc collapsed dramatically. Remnants of this system, as well as a culture of public health overemphasising the importance of clinical medicine, survived in many Central and Eastern European countries, including Poland, after the fall of the Eastern Bloc in the early 1990s. This applies not only to the way of thinking about patients and healthcare providers, but also public health administration officials $[11,14,15]$.

The next step in the fight against cervical cancer was the invention of a vaccine against $\operatorname{HPV}[8,16,17]$. The vaccine has been introduced in many countries, including most states of the European Union, in the form of national vaccination programmes [18]. There are some early signs that vaccination can effectively help to reduce the prevalence of and deaths from cervical cancer $[19,20]$. At the beginning of the $21^{\text {st }}$ century, our knowledge on the biology, etiology, diagnosis, prevention, and treatment of cervical cancer is close to complete [21]. In a recent issue of The New England Journal of Medicine, Tsu and Jeronimo wrote that while "no woman should die of cervical cancer in this day and age $[. .$.$] without screening and preventive$ treatment, some 19 million will die from cervical cancer over the next 40 years" [19].

The goal of this analysis is to compare the time trends in cervical cancer mortality in young adult women in three selected European Union countries: Finland, Poland, and Latvia. The analysis focuses on mortality in the group of young adult women (aged 20-44 years) because the good completeness and quality of cancer diagnosis and statistics make it a good indicator determining the status of cervical cancer control.

\section{MATERIAL AND METHODS}

The study is based on mortality data on cervical cancer derived from the World Health Organisation (WHO) Mortality Database between 1960 and 2013 (except for Latvia where data were available for the period 1980-2012) [22]. The database contains information about the number of deaths by causes defined in the International Classification of Diseases (ICD), provided according to gender, age, and calendar year. The study analysed the standardised mortality rates due to cervical cancer in Finland, Poland, and Latvia as 
specified in the ICD-7 number 171 (data from 1960 to 1968), in ICD-8 (1969-1980), and ICD-9 (1981-1996) number 180 and ICD-10 (1999-2013) code C53. The world standard population has been used to calculate standardised mortality rates.

\section{RESULTS}

The results of the analysis have demonstrated distinct patterns in time trends of cervical cancer mortality between the three countries of the European Union included in the analysis (Fig. 2), with a particularly pronounced divergence between Poland and Latvia after 1990.

In Finland, cervical cancer mortality is almost completely under control. The incidence and mortality rates peaked in 1960s [23]. This was followed by a steep decrease of mortality rates between 1960 and 1973, when mortality averaged under 1 death per 100,000 (Fig. 2). This entire process took less than 20 years. Since then, the mortality level has remained constant (in the range from 0.3 to 1.4) until the end of observation period.

In Poland, until the end of the 1980s, cervical cancer mortality rates have maintained a constant level of a few deaths per 100,000 population per year (Fig. 2). At the beginning of 1990s, mortality trends began to decline sharply, and this decline has continued since then. Generally, despite the time delay, the trends in Poland were identical to those observed in Western European countries, including Finland, a few decades earlier.

In contrast, in Latvia, after a period of fluctuation in the 1980s, a steep linear increase of cervical cancer mortality in young adult women has been observed from $1.3 / 100,000$ in 1991 to $7.1 / 100,000$ population in 2010 (Fig. 2).

\section{DISCUSSION}

Finland constitutes a particularly successful example of a country that has built and implemented an efficient and effective system of population-based early diagnosis and treatment of cervical cancer. For many years, it has been has been an integral part of the health care system in this country. Screening in Finland is science and evidence-based [24], conducted by civil society (Finnish Cancer Society), with strong collaboration of goverment. It was also the most cost-effective programme in Europe [25]. The screening has covered almost the entire female population in Finland [23, 26, 27], and although a $60 \%$ increase in cervical cancer incidence in the population aged under 55 years was documented by the Finnish Cancer Registry [23], it did not affect the mortality trends after 1990 (Fig. 3), confirming the efficiency of the screening programme. In former socialist economy countries, which did not implement screening (e.g. Latvia or Bulgaria), and in other European countries conducting cervical cancer screenings (e.g. Ireland or $\mathrm{UK})$, an increase in incidence often led to a subsequent increase in cervical cancer mortality $[23,28]$. The cost effectiveness of the cervical cancer programme in Finland is confirmed by the fact that a Finnish woman on average performs the Pap test seven times during their lifetime, while in Germany, a country with similar cervical cancer incidence and mortality rates, women conduct approximately fifty Pap tests [29].

Cervical cancer transformation in Poland was delayed by at least 30 years compared to Finland. Initially, after the socio-economic transformation in 1989, screening started to be conducted on an opportunistic basis. A nationwide 10-year programme of cervical
A

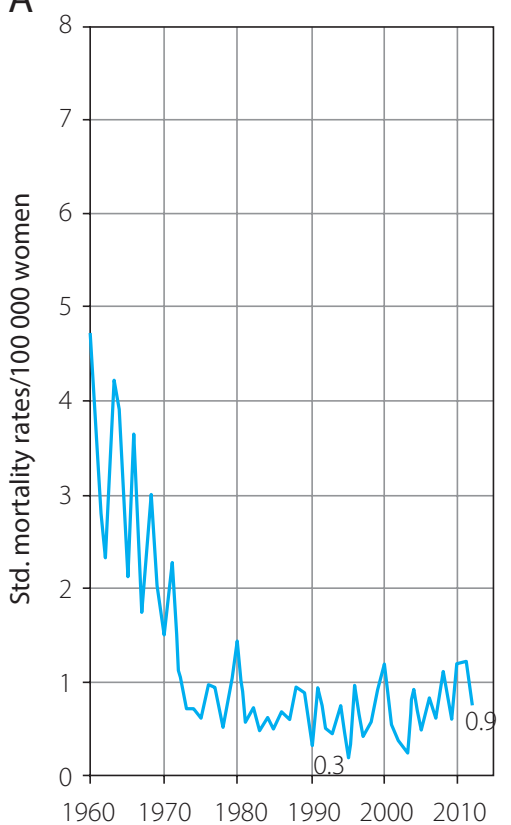

B

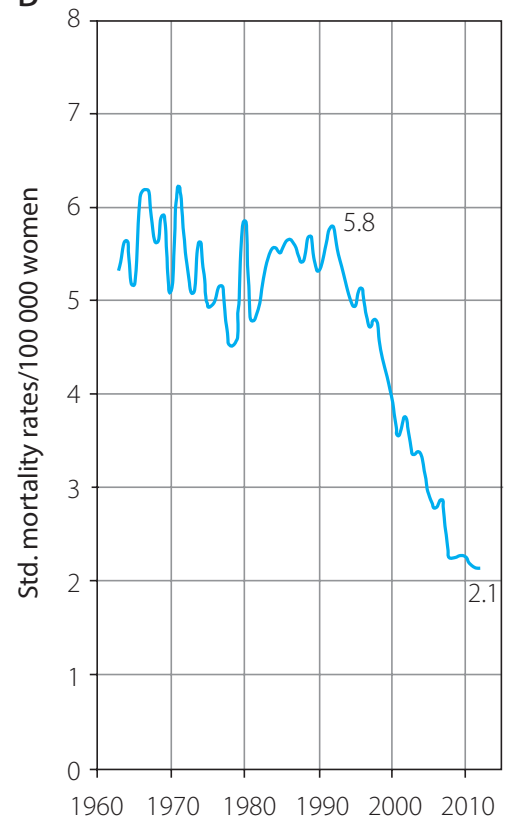

C

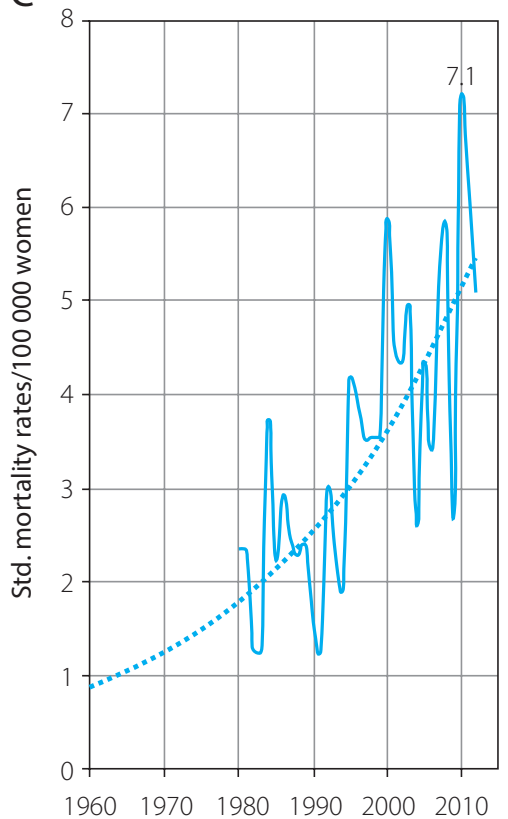

FIG. 2. Cervical cancer standardised mortality rates in Finland (A), Poland (B), and Latvia (C), women aged 20-44 years, $1960-2012$ 
cancer control has been designed in the early 2000s and introduced in 2006 as part of the National Cancer Control Programme [30]. From 2006, an organised population-based model of screening was implemented, in which the sending of invitation letters was accompanied by educational activities. This National Population-Based Cervical Cancer Screening Programme was aimed to improve the detection of precancerous lesions and early stage cervical cancer. The Programme has been implemented and administered by one national and sixteen regional coordination centers [31-33]. These centers were responsible for sending individual invitations for women to perform Pap tests, for conducting educational and media campaigns to raise the knowledge on prevention of cervical cancer, and to increase the attendance in the Programme, as well as for the monitoring, evaluation, and quality control of the Programme [31]. On the whole, the Programme that ran in Poland between 2006 and 2015, was successful in all age groups but especially in young adult women. From being the country with the highest cervical cancer mortality rates in Europe in 1990 (alongside Romania and Hungary), Poland by 2012 managed to bring down the mortality rates among women aged $20-44$ by two-thirds, to lower levels than in Luxembourg, Ireland, or Denmark (Fig. 3).

However, cervical cancer control in Poland is still facing many challenges. Currently, the most serious of these are the substantially higher mortality rates in women

A

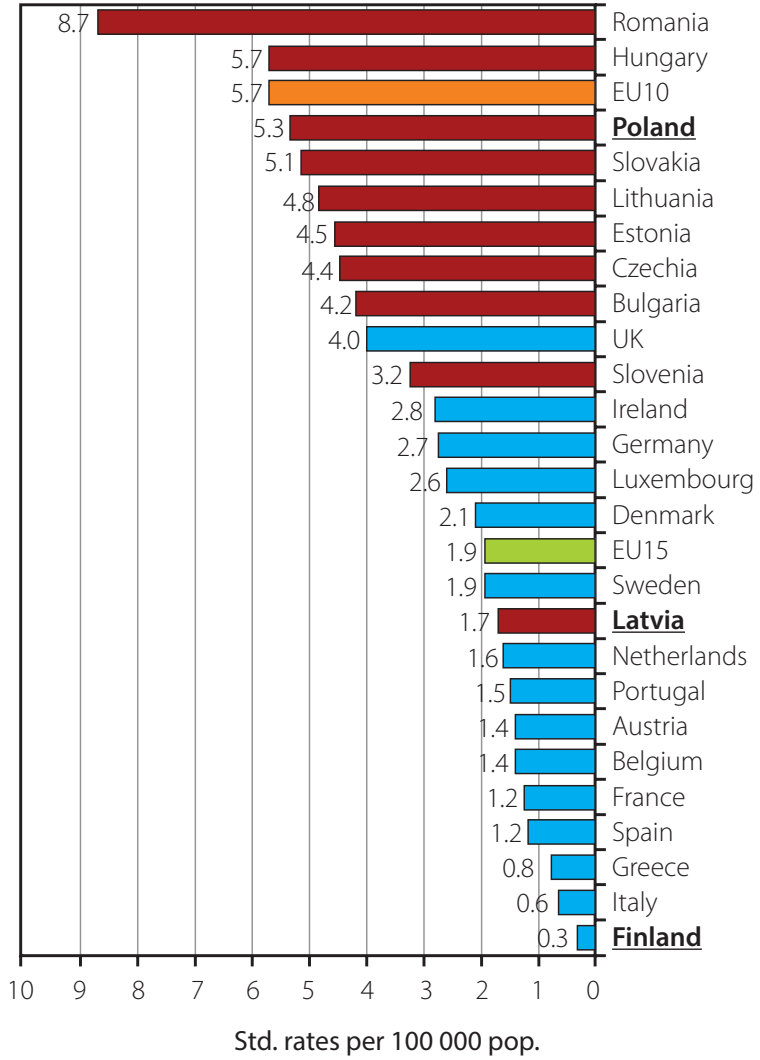

with a lower education level and lower economic status. Cervical cancer in young adults is approximately 10 times higher among less educated women compared to those with higher education [21]. Furthermore, significantly higher mortality rates can be observed among women from rural areas and small cities, in comparison to women living in large urban agglomerations. The lower educated, lower socio-economic, rural groups are characterised by a high proportion of women who have never undertaken a Pap test (50\%) [21]. It seems that there is a possibility of relatively fast improvement in screening activities pay particular attention to the socio-economic groups of women with higher risk of cervical cancer, and especially those who have never performed a Pap test. Nonetheless, the challenges associated with conducting a well-organised, high quality population-based screening among these groups remain substantial. For more information, see the last issue of the Journal of Health Inequalities [21].

The development of the cervical cancer situation in Latvia exhibits the most complicated pattern of the three countries included in analysis. Latvia started its socio-economic transformation in 1990s with one of the lowest cervical cancer mortality rates in young adult women among current European Union countries (Fig. 3). However, between 1990 and 2012, its cervical cancer mortality rates among women aged 20-44 increased to one of the highest levels in the European

B

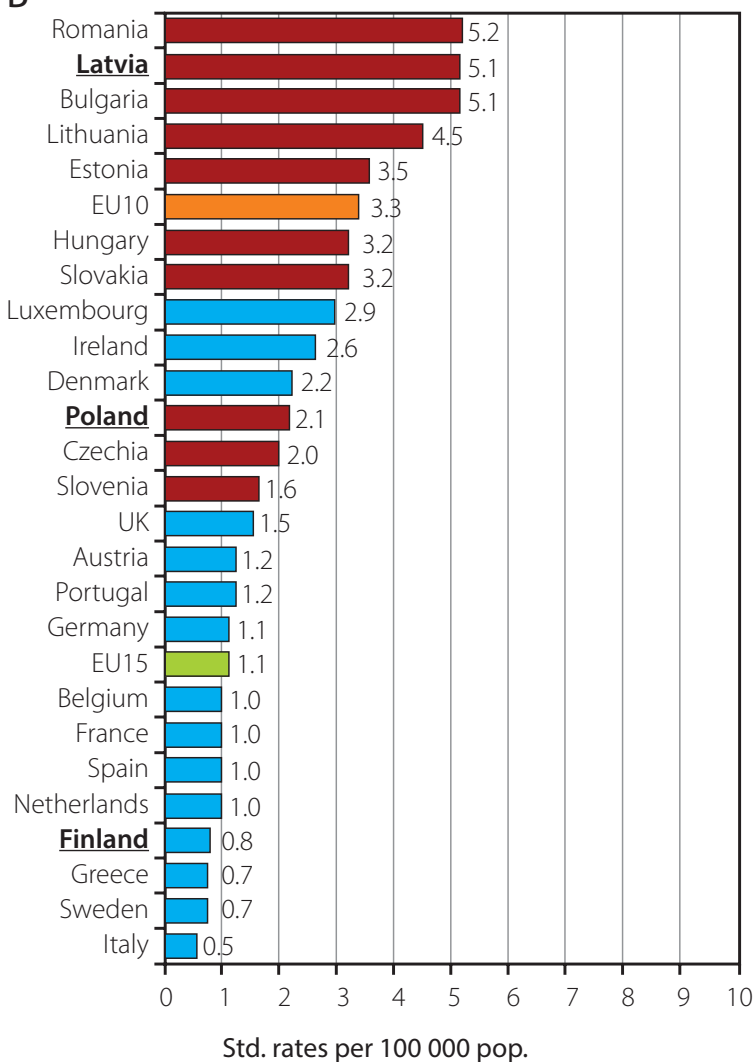

FIG. 3. Cervical cancer mortality in women in the age group 20-44, 1990 (A) and 2012 (B) 
Union, alongside Romania and Bulgaria (Fig. 3). Recent publications have linked this dramatic increase of incidence and mortality (Fig. 2) with the changes in the system of early diagnosis and treatment of cervical cancer in Latvia. Screening towards cervical cancer ceased to be the domain of specialised gyneacologists, and instead, was assigned to general practitioners [13]. Further research is needed to get a fuller epidemiological, sociological, and economic understanding of this negative trend.

\section{CONCLUSIONS}

To sum up, data suggest that in many countries of Western Europe the problem of cervical cancer mortality is almost completely controlled. In Central and Eastern European countries, such as Slovenia, Czech Republic, or Poland, cervical cancer mortality continues to demonstrate a decreasing trend. Finally, in several countries, especially the Baltic states (Latvia, Lithuania, Estonia) but also in Bulgaria and Romania, cervical cancer mortality has showed unexpected strict increases (Fig. 3) and fluctuations in the last decades [12].

In Central and Eastern European countries, the attempts to control cervical cancer are still incomplete. One of the problems is the lack of a sustainable and longterm strategy for conducting cervical cancer screenings. An example of this is the Polish screening programme, which after successfully improving cervical cancer mortality rates in last decades was terminated at the beginning of 2016. The Regional Coordination Center for Population Programme of Prevention and Early Diagnosis of Cervical Cancer in Wielkopolska ${ }^{1}$ region, which was the first national coordination center, and which played particularly important role in the creation and implementation of the cervical cancer control programme in Poland, was closed down on $1^{\text {st }}$ January 2016 [34]. Surprisingly, after 10 years of building capacity and infrastructure, training personnel, and conducting educational activities, its activity was put to a standstill. Although it is still possible to perform a free Pap test in Poland (the cost of which is refunded by the National Health Fund), individual invitation letters, which are the basis of effective population-based organised screenings, will not be sent out anymore, and educational activities have been suspended.

In the last edition of the European Code Against Cancer [35], cervical cancer control is still listed as a public health priority. The Code became a very important element of educational activities in many European countries. In Poland, the dissemination of the Code was very effective and acknowledged by the Association of European Cancer Leagues (ECL) as one of the most thorough dissemination campaigns in the European Union. It would be advisable that the ECL, as well as countries with established effective cervical cancer screening pro-

\footnotetext{
${ }^{1}$ Wielkopolska is a region of West-Central Poland. Its capital city is Poznan.
}

gramme, create and help implement programme supporting other European countries, which experience unfavorable cervical cancer trends. This coordinated effort would allow to minimise the health and social consequences of cervical cancer across Europe.

The European Observatory of Health Inequalities in Kalisz has undertaken an initiative to prepare a programme for reduction of cervical cancer mortality among Polish women to the level achieved in Finland by 2030. The Observatory will conduct a comprehensive analysis of cervical cancer mortality in Poland and other Central and Eastern European countries, and prepare a proposal for a comprehensive set of activities, tools, and organisational undertakings. As a first step in this direction, the Provost of the Higher Vocational State School in Kalisz, Professor Magdalena Pisarska-Krawczyk, decided that the main subject of the Women's Health Congress that will take part in Kalisz in June 2017 will be the eradication of cervical cancer in Poland. Among the themes of the conference will be "Zero tolerance towards the 1,500 cervical cancer deaths each year in Poland", as well as "Wielkopolska-Kalisz as the first region to eliminate cervical cancer deaths by 2030 ".

\section{ACKNOWLEDGMENTS}

Authors of the publication would like to thank Diana Baranowska and Mateusz Zatonski for help in preparing the manuscript.

\section{DISCLOSURE}

Authors report no conflict of interest.

\section{References}

1. International Agency for Research on Cancer. World Cancer Report 2014. World Health Organization, Geneva 2014.

2. Word Health Organization, International Agency for Research on Cancer. Cervix Cancer Screening. IARC Handbooks of Cancer Prevention, vol. 10. IARC Press, Lyon 2005.

3. Arbyn M, Autier P, Ferlay J. Burden of cervical cancer in the 27 member states of the European Union: estimates for 2004. Ann Oncol 2007; 18: 1423-1425.

4. Kesic V, Poljak M, Rogovskaya S. Cervical cancer burden and prevention activities in Europe. Cancer Epidemiol Biomarkers Prev 2012; 21: 1423-1433.

5. Jablonska S, Milewski B. Zur Kenntnis der Epidermodysplasia Verruciformis Lewandowsky-Lutz. Dermatologica 1957; 115: 1-22.

6. Jablonska S, Dabrowski J, Jakubowicz K. Epidermodysplasia verruciformis as a model in studies on the role of papovaviruses in oncogenesis. Cancer Res 1972; 32: 583-589.

7. Orth G, Jablonska S, Favre M, Croissant O, et al. Characterization of two types of human papillomaviruses in lesions of epidermodysplasia verruciformis. Proc Natl Acad Sci USA 1978; 75: 1537-1541

8. Zur Hausen H. Papillomaviruses in the causation of human cancers - a brief historical account. Virology 2009; 384: 260-265.

9. Bosch FX, Manos MM, Muñoz N, Sherman M, Jansen AM, Peto J, Schiffman MH, Moreno V, Kurman R, Shah KV, Alihonou E, 
Bayo S, Cherif Mokhtar H, Chichareon S, Daudt A, de los Rios E, Ghadirian P, Kitinya JN, Koulibaly M, Ngelangel C, Puig TintoreLM, Rios-DalenzJL, Sarjadi A, Schneider A, TafurL, Teyssie AR, Roln PA, Torroella M, Vila Tapia A, Wabinga HR, Zatonski W, Sylla B, Vizcaino P, Magnin D, Kaldor J, Greer C, Wheeler C. Prevalence of human papillomavirus in cervical cancer: a worldwide perspective. International biological study on cervical cancer (IBSCC) Study Group. J Natl Cancer Inst 1995; 87: 796-802.

10. Bardin A, Vaccarella S, Clifford GM, Lissowska J, Rekosz M, Bobkiewicz P, Kupryjańczyk J, Krynicki R, Jonska-Gmyrek J, Danska-Bidzinska A, Snijders PJ, Meijer CJ, Zatonski W, Franceschi S. Human papillomavirus infection in women with and without cervical cancer in Warsaw, Poland. Eur J Cancer 2008; 44: 557-564.

11. Zatoński WA, Zatoński M. Health in the Polish People’s Republic. J Health Inequal 2016; 2: 7-16.

12. Vaccarella S, Franceschi S, Zaridze D, et al. Preventable fractions of cervical cancer via effective screening in six Baltic, central, and eastern European countries 2017-40: a population-based study. Lancet Oncol 2016; 17: 1445-1452.

13. Viberga I, Engele L, Baili P, et al. Past, present, and future of the cervical cancer screening in Latvia. Tumori 2010; 96: 529-537.

14. Zatoński W and the HEM Project Team. Closing the health gap in European Union. Cancer Center and Institute, Warsaw 2008.

15. Zatoński WA and the HEM Project Team. Epidemiological analysis of health situation development in Europe and its causes until 1990. Ann Agric Environ Med 2011; 18: 194-202.

16. World Health Organization. Human papillomavirus vaccines: WHO position paper, October 2014. Wkly Epidemiol Rec 2014; 89: 465-491.

17. Naud PS, Roteli-Martins CM, De Carvalho NS, et al. Sustained efficacy, immunogenicity, and safety of the HPV-16/ 18 AS04-adjuvanted vaccine: final analysis of a long-term follow-up study up to 9.4 years post-vaccination. Hum Vaccin Immunother 2014; 10: 2147-2162.

18. European Centre for Disease Prevention and Control. Introduction of HPV vaccines in European Union countries - an update. Stockholm: ECDC, 2012, Available from: http://ecdc. europa.eu/en/publications/Publications/20120905_GUI_ HPV_vaccine_update.pdf (accessed on 25 August 2016).

19. Tsu V, Jeronimo J. Saving the world's women from cervical cancer. NEJM 2016; 374: 2509-2511.

20. Markowitz LE, Liu G, Hariri S, et al. Prevalence of HPV after introduction of the vaccination program in the United States. Pediatrics 2016; 137: 1-9.

21. Wojtyła C, Słabuszewska-Jóźwiak A, Janik-Koncewicz K, Zatoński WA. New challenges for cervical cancer. J Health Inequal 2016; 2: $77-88$.

22. World Health Organization Mortality Database. Health and statistic information systems, 2014. Available from: http://www. who. int/healthinfo/mortality_data/en/ (accessed on 15 August 2016).

23. Anttila A, Pukkala E, Söderman B, et al. Effect of organized screening on cervical cancer incidence and mortality in Finland, 1963-1995: recent increase in cervical cancer incidence. Int J Cancer 1999; 83: 59-65.

24. Hakama M, Miller AB, Day NE. Screening for cancer of the uterine cervix. IARC Sci Publ 76. IARC, Lyon 1986.
25. Coleman MP, Alexe DM, Albreht T, et al. (eds.). Responding to the challenge of cancer in Europe. Institute of Public Health of the Republic of Slovenia, Ljubljana 2008.

26. Nieminen P, Kallio M, Hakama M. The effect of mass screening on incidence and mortality of squamous and adenocarcinoma of cervix uteri. Obstet Gynecol 1995; 85: 1017-1021.

27. Hristova L, Hakama M. Effect of screening for cancer in the Nordic countries on deaths, cost and quality of life up to the year 2017. Acta Oncol 1997; 36 Suppl 9: 1-60.

28. Levi F, Lucchini F, Negri E, et al. Cervical cancer mortality in young women in Europe: patterns and trends. Eur J Cancer 2000; 36: 2266-2271.

29. Mandelblatt J, Lawrence W, Gaffikin L, et al. Costs and benefits of different strategies to screen for cervical cancer in less-developed countries. JNCI 2002; 94: 1469-1483.

30. Dz. U. 2005 nr 143, poz. 1200. Ustawa z dnia 1 lipca 2005 r. o ustanowieniu programu wieloletniego „Narodowy program zwalczania chorób nowotworowych” [Journal of Laws of the Republic of Poland, 2005, No 143, Pos. 1200. Law from 1 July 2005 regarding establishing long-term program "National program on cancer control"].

31. Januszek-Michalecka L, Nowak-Markwitz E, Banach P, et al. Effectiveness of the National Population-Based Cervical Cancer screening Programme in Poland - Outcomes, problems and possible solutions 7 years after implementation. AAEM 2013; 20: 859-864.

32. Spaczyński M, Michalska M, Januszek-Michalecka L. Centralny Ośrodek Koordynujący. Raport z realizacji Populacyjnego Programu Profilaktyki i Wczesnego Wykrywania Raka Szyjki Macicy za okres 01.01.2008 do 31.12.2008. [Central Coordinating Center. Summary of the National Cervical Cancer Screening Program in Poland from January $1^{\text {st }}$ till December 31 ${ }^{\text {st }}$ 2008]. Ginekol Pol 2009; 80: 220-226.

33. Rekosz M, Karska A, Osiecka-Tęsny E, et al. 15 lat aktywnych badań przesiewowych raka szyjki macicy prowadzonych przez centrum onkologii - dotychczasowe rezultaty. Nowotwory. Journal of Oncology 2003; 53 (Suppl 2): 62-69.

34. Populacyjny Program Profilaktyki i Wczesnego Wykrywania Raka Szyjki Macicy [Population-Based Program for Prevention and Early Diagnosis of Cervical Cancer]. Available from: http://www.gpsk.am.poznan.pl/profilaktyka-raka-szyjki-macicy/populacyjny-program-profilaktyki-i-wczesnego-wykrywania-raka-szyjki-macicy.html (accessed 30 November 2016).

35. Schüz J, Espina C, Villain P, Herrero R, Leon ME, Minozzi S, RomieuI, Segnan N, WardleJ, Wiseman M, BelardelliF, BettcherD, Cavalli F, Galea G, Lenoir G, Martin-Moreno JM, Nicula FA, Olsen JH, Patnick J, Primic-Zakelj M, Puska P, van Leeuwen FE, Wiestler O, Zatonski W; Working Groups of Scientific Experts. European Code against Cancer $4^{\text {th }}$ Edition: 12 ways to reduce your cancer risk. Cancer Epidemiol 2015; 39 (Suppl 1): S1-10.

\section{AUTHORS' CONTRIBUTIONS}

WAZ prepared the research concept and design of the article. WAZ, CW and KJK analysed data, interpreted and wrote the article. WAZ and MPK finally approved the publication. 